\title{
INTRODUCTION:
}

\section{THE STORIES WE TELL}

To pay for my father's funeral

I borrowed money from people

He already owed money to.

One called him a nobody.

No, I said, he was a failure.

You can't remember

A nobody's name, that's why

They're called nobodies.

Failures are unforgettable.

_Philip Schultz, "Failure"

A man of genius makes no mistakes; his errors are volitional and are the portals of discovery.

\section{-James Joyce, Ulysses}

Jews, said Rabbi Nahman of Bratslav, as opposed to other cultures, do not tell stories to lull children to sleep but rather to wake them up. But what are those stories, in fact, that wake us up? Typically, Jewish storytelling is associated with lofty tales of hagiographic piety that recount the greatness and righteous deeds of religious leaders. This, however, is not one of those stories. This is a story of sin and failure and its place within Jewish thought and life. It is not a racy exposé or tell-all but a frank and honest discussion of some of the lesser known aspects of sin and failure and their place within Judaism. Ultimately it is a story that I hope wakes up some who seem to be drifting asleep. 
Judaism has a complex relationship with failure and sin, particularly as it relates to storytelling. In 2002 Rabbi Nathan Kaminetsky published a book entitled Making of a Godol. The book was intended to be a multi-volume biography of his father, Rabbi Yaakov Kaminetsky (1891-1986). Only one volume, which covered the first two decades of his father's life, was published. As a book it is nearly unreadable. There are a little more than sixty pages covering the sequential life of Rabbi Yaakov's early years; the other twelve hundred pages or so comprise confusing footnotes and excurses delving into each detailed aspect of his life. When it was first published, hardly anyone cared to read it. And then it was banned. ${ }^{1}$ A group of rabbis in Israel felt that the book was disparaging of the Jewish leaders of previous generations. Their claim was not without merit. Making of a Godol is certainly not your typical religious storybook. For outsiders to the Orthodox community the offending passages seem entirely innocuous. But for those who were raised listening to their parents read saintly tales of rabbis from previous generations, it was certainly jarring to discover that Rabbi Aharon Kotler wrote love letters to his fiancée. Or that the famed Rabbi Yisrael Meir Kagan, known as the Hafetz Hayyim, struggled with depression. Or that Rabbi Yisrael Salanter smoked cigarettes. These were not the stories that mothers told their children. Jewish stories, it seemed, should be carefully sanitized to avoid sullying the reputation of their protagonists or, more dreadfully, the ears of the reader.

Sanitized stories and ideas are certainly an important part of Jewish education. Rabbi Shimon Schwab admirably defended the importance of sanitized storytelling. He writes:

What ethical purpose is served by preserving a realistic historic picture? Nothing but the satisfaction of curiosity. We should tell ourselves and our children the good memories of the good people, their unshakeable faith, their staunch defense of tradition, their life of truth, their impeccable honesty, their boundless charity and their great reverence for Torah and Torah sages. What is gained by pointing out their inadequacies and their contradictions? We want to be inspired by their example and learn from their experience. ${ }^{2}$

He is not wrong. I, for one, am glad that my mother did not tuck me in at night reading to me the litany of mistakes and infractions committed by rabbis throughout history. It does not bother me when I read a rabbinic biography that exclusively recounts the piety and holiness of leaders from previous generations. In fact I find it inspiring. Others may find that 
sanitized stories are left with a hospital-like, uncomfortable odor when they are stripped of their more historical-and often borderline-hereticalaspects. I don't. So why spend so much time discussing sin and failure?

\section{The Stories We Tell}

An Emory University study illuminates the importance of discussing sin and failure. Dr. Marshall Duke, along with his Emory colleagues Robyn Fivush and Jennifer G. Bohanek, designed a survey called "Do You Know," which asks children questions about their family narrative. ${ }^{3}$ Do you know how your parents met? Do you know where your grandparents grew up? Which person in the family do you act most like? They formed a list of twenty questions about family narrative and discovered that the more children knew about their family, the better they thrived when faced with adversity. Based on these questions, they then explored the different sorts of narratives that shape families. As recounted by Bruce Feiler in his New York Times column "The Stories That Bind Us," they found there are essentially three thematic narratives that families tell. Feiler writes:

First, the ascending family narrative: "Son, when we came to this country, we had nothing. Our family worked. We opened a store. Your grandfather went to high school. Your father went to college. And now you. ... Second is the descending narrative: "Sweetheart, we used to have it all. Then we lost everything." 4

The narrative, however, that cultivated the most resilience and strength among families was the third type, which Duke calls "the oscillating family narrative." This form of family narrative integrates moments of successwealth, marriages, promotions-with moments of failure such as illness, layoffs, and death. When children hear their family's oscillating narrative and know that nonetheless their family persevered, a sense of courage and resilience is conveyed that will allow them to transcend their own moments of tribulation. "The bottom line," writes Feiler, "if you want a happier family, create, refine, and retell the story of your family's positive moments and your ability to bounce back from the difficult ones. That act alone may increase the odds that your family will thrive for many generations to come."

Like family, religion is also a story. It begins with biblical stories but is perpetuated with the continued traditions each family tells. Moments of 
doubt, moments of inspiration, transitions toward observance and journeys away-our religious practice is informed by different forms of narrative. The Bible itself compares life to a book, each life containing a different story. ${ }^{5}$

What stories, then, does Judaism tell? For many it is an ascending narrative with a secular beginning and a religious destination. Others follow a descending narrative in which religious life was primarily an exit door from behavioral constraints and theological frustration. I hope this book, with its candid look at sin and failure, helps others develop an oscillating narrative about their Judaism. Granted, sin and failure cannot be the only stories we tell, and this book thus shouldn't be the only book on anyone's shelf. But a book about sin still serves a purpose of sorts and its presence on our shelf helps ensure we tell the right stories.

Rabbi Yitzhak Hutner (1906-80) was no stranger to oscillating narratives. Born in Warsaw, he narrowly missed the 1929 massacre in Hevron. He spent time studying at the University of Berlin before eventually settling in the United States, where he led Yeshivat Rabbeinu Chaim Berlin in Brooklyn. In September 1970, while traveling with his daughter, her husband, and a student, his plane was hijacked by the Popular Front for the Liberation of Palestine. Throughout the harrowing ordeal he managed to maintain his dignity. When offered a can of soda by one of the terrorists, Rabbi Hutner, known for his sharp wit and humor, reminded the terrorist that he prefers his Pepsi cold. While he survived the ordeal, a finished manuscript of his book on Shavuot was lost and had to be rewritten from scratch. Aside from the theologically complex and sophisticated volumes of writing he left, Rabbi Hutner also stands out as a moving advocate for the oscillating narrative, particularly in his published correspondence.

"Everyone is in awe of the Hafetz Hayyim," writes Rabbi Hutner, referring to Rabbi Yisrael Meir Kagan of Radin (1838-1933), who wrote a famed compendium on proper speech in Jewish law. ${ }^{6}$ But who actually considers, he asks, how many struggles, difficulties, and battles the Hafetz Hayyim had to wage in order to develop his famed meticulousness with language? This is likely the most oft-cited letter of Rabbi Hutner and for good reason. The letter, which begins by lamenting the hagiographic nature of rabbinic narratives, reminds a student that greatness does not emerge from the serenity of our good inclinations but from our struggles with our baser tendencies. The verse in Proverbs (24:16), "the righteous fall seven times and stand up," has been perennially misunderstood. It is not despite this failure that the 
righteous stand up-it is because of the fall that the righteous are able to stand confidently. Greatness does not emerge despite failure; it is a product of failure.

But our narratives, both personal and religious, have become warped. We think of success as a sequential line that over the course of time points upwards. Instead, success in any endeavor is a winding, meandering journey with many false starts, unfulfilled promises, and public failures. The distinction between the straight, sequential narratives we tell and those more winding and twisted stories we actually live are reflected in the Hebrew words for song. Throughout Psalms, the words shir [שיר] and mizmor [מזמר] frequently appear as synonyms for hymns. What is the difference between the words shir and mizmor? A shir shares the same root as the word shura [שורה], the Hebrew word for straight line. Shirah are our songs of appreciation for those sequential moments of accomplishment in our life as well as prayers that the trajectory of our life should proceed accordingly. The root of the word mizmor is zemer [זר] -the Hebrew word for a vine. Vines loop, twist, and curve. During moments of setback and failure, mizmor is a reminder that those moments are part of our song as well. Life surely will be comprised of lines and vines, moments of shir and mizmor-both, however, must be sung.

\section{Our Story, in Blurbs}

Nothing highlights our complicated relationship with religious narrative better than the narratives we tell about ourselves. But when, honestly, are we ever telling our narrative truthfully? The culprit for our narrative neurosis is the typical structure of our bio blurbs. You may have seen a bio blurb for an author or a scholar-in-residence. They look something like this: ${ }^{7}$

After graduating from Harvard University, John Leiner received the prestigious MacArthur Genius Grant. A gifted teacher who has lectured throughout the world, Dr. Leiner is currently the CEO of the Leiner Foundation. His daily insights can be found at JohnLeiner.com.

Sound familiar?

I find bio blurbs very eerie, like looking at a photoshopped family photo. Vague phrases are always used like "sought-after speaker" and "internationally-renowned" that would seem narcissistic if spoken but are strangely accepted practice in bio blurb writing etiquette. 
The absurdity of the bio blurb is only fully realized after writing one's own. The first realization that immediately descends is that everyone writes his own bio blurb. Granted, we collectively suspend disbelief and pretend it came from our personal PR department, but privately we all smirk as we imagine our friends and mentors struggling over which superlatives they could convincingly describe themselves with.

As Orwell noted, "Autobiography is only to be trusted when it reveals something disgraceful. A man who gives a good account of himself is probably lying." If good biographies tell a proper story of nonsequential success, bio blurbs are the fun house mirrors that portray success as a pristine linear progression without the blemish of failure. But a bio blurb that is merely successes-our own ESPN highlight reel-sends the wrong message to others and paints a stilted portrait of ourselves.

Rabbi Menachem Mendel Morgenstern, the famed rabbi of Kotzk, once said, "I like to keep my good deeds private and my failures public." Of course we should be proud of our successes, but both for a more honest reflection of life and as a sign of encouragement and solidarity to anyone who has just received a first (or fiftieth) thin envelope, perhaps we can do a better job of integrating life's failures within our typically self-obsessed bio blurbs. It's great to list all of your successes in three to five short sentences, but maybe if one of those sentences were a failed project, rejected application, or unexpected difficulty, even our successes would seem more lively. It may only take one sentence to remind yourself that you can laugh at yourself. It's only one sentence to tell others that life will always have its disappointments. It's a one sentence tribute to one of the thin envelopes you have received in your life.

I am not suggesting a major revolution, just a cute little ploy that might help paint a more accurate picture of your life's oscillating narrative. ${ }^{9}$

In fact, I'll start with mine.

David Bashevkin is the Director of Education for National NCSY and is pursuing a doctorate in public policy and management at The New School's Milano School of International Affairs. He was rejected from the Wexner Graduate Fellowship. Twice. 